\title{
Fånglägret i Dragsvik 1918 - vägen till en humanitär katastrof
}

Fysiologiprofessorn Robert Tigerstedt, nyutnämnd överläkare för rannsakningslägret i Dragsvik utanför Ekenäs, gjorde i månadsskiftet juli-augusti I9I8 en ingående granskning av de hygieniska förhållandena på det tidigare ryska militärområdet, som vid den tidpunkten hyste runt 6 ooo röda fångar. Den 65-årige dekanen för medicinska fakulteten vid universitetet i Helsingfors betecknade det han såg som en katastrof. Enligt rapporten till krigsfångeväsendets överläkare hade under knappa åtta veckor, från den 6 juni till den $3 \mathrm{I}$ juli, inte mindre än I 347 fångar avlidit i fånglägret. Tigerstedt räknade ut att dödligheten var 42,33 promille i veckan.

Något motsvarande torde knappast ens i tsardömets fängelser hava förekommit, eller, om sådant varit fallet, har då det haft sin grund i någon smittosam epidemisk sjukdom, kolera, koppor eller dylikt, men icke berott på en i högsta grad ohygienisk behandling av fångarna. ${ }^{1}$

Efter inbördeskrigets slut i maj I9I8 hade den segrande vita sidan tagit mellan 75000 och 80 ooo fångar och beslutat att låta rannsaka alla tillfångatagna om deras eventuella andel i det röda upproret. Under tiden skulle de hållas internerade $\mathrm{i}$ olika läger. Beslutet förde under de närmaste månaderna runt $\mathrm{I} 3500$ finländare $\mathrm{i}$ en för tidig grav.

För skötseln av fångfrågan upprättade armén våren I9I8 krigsfångeväsendet SVL (Sotavankilaitos). Det gjordes till en underavdelning

I. Robert Tigerstedt, "Rapport angående de hygieniska förhållandena i fånglägret vid Ekenäs", 5/8 I9I8. Brev till överläkaren, nr 2II, Ee I, Krigsfångeväsendets arkiv, Riksarkivet, Helsingfors. 
av takorganisationen VATO (Valloitettujen alueiden turvaamisosasto, Avdelningen för säkrandet av de erövrade områdena), som under det militära högkvarterets kontroll tog hand om det röda upprorets efterspel. SVL fick i uppgift att organisera ett omfattande fånglägersystem. I brådskande ordning upprättades ett ambitiöst undersökningsväsende för förhör av fångarna, samtidigt som uppgifter om dem inhämtades från församlingarna och skyddskårerna på deras hemorter. Allt material skulle sedan samlas i Helsingfors som en grund för arbetet i de statsförbrytelsedomstolar som man bildade vid denna tid. Ansvaret både för fångarna och rannsakningen låg hos armén. Fångfrågan kom därmed att utgöra en del av det som Jaakko Paavolainen betecknat som en "militärdiktatur" i Finland våren r9ı. ${ }^{2}$

Som lämpliga förvaringsplatser för fångarna framstod de övergivna ryska kasernområdena i landet. Till Dragsvik fördes under sommaren i runt tal to ooo fångar. Vid midsommartiden trängdes där på en gång mer än 8 6oo. På bara några månader avled omkring 3 ooo fångar, som lades i vad som blev Finlands största massgrav, på åsen strax utanför det som i dag är Nylands brigad. ${ }^{3}$

Att fångarna hotades av massdöd blev snart uppenbart för myndigheterna. Senaten beslöt därför den 26 juni att de minst skyldiga fångarna omedelbart skulle friges. ${ }^{4}$ Från Dragsvik försattes före den I augusti I 240 fångar på fri fot i väntan på rättegång. Via statsförbrytelsedomstolarna, som i Ekenäs kom igång med sin verksamhet den ro juli, öppnades under juli lägerportarna för 454 fångar. Den I augusti var fångarna i Dragsvik 6027 till antalet. ${ }^{5}$

2. Jaakko Paavolainen, Vankileirit Suomessa I9I8, Helsinki: Tammi ı97ı, s. 89-90.

3. Det exakta antalet dödsoffer i Ekenäs är oklart. De officiella halvveckorapporterna från I9I8 omnämner 2530 döda i Dragsvik, medan Jouni Eerola, Ekenäs I9I8, [Ekenäs: Centralkommittén för 70-årsminnesevenemanget över Ekenäs fångläger] I989, s. I9, noterar 2873 dödsoffer utgående från den dödsbok som uppgjordes i lägret. Det av statsrådet initierade projektet Krigsdöda I9I4-22 resulterade i 394 nya namn på massgravens minnestavlor, som började uppföras 1988 och hösten 2017 omfattade hela 3446 namn. Tavlorna innehåller dock en del felaktigheter och namn som förekommer dubbelt, och en översyn hösten 2017 gav totalresultatet 3 O4I namn. Tauno Tukkinen hävdar i Tammisaaren vankileirillä kuolleet punaiset I9I8, Karjalohja: TT 20I7, s. 8, att det riktiga antalet döda i Dragsvik är 2900.

4. Paavolainen, Vankileirit Suomessa, s. II8 f.

5. Halvveckorapporterna från Dragsvik, Ec 4, Krigsfångeväsendets arkiv, Riksarkivet, Helsingfors. 
Trots detta förvärrades dödligheten bland fångarna under juli, då i medeltal drygt 30 personer per dag avled i Dragsvik. Den 20 juli bars hela 65 lik upp till massgraven. Dragsvik stod ensamt för drygt 40 procent av alla landets fånglägerdödsfall $\mathrm{i}$ juli. Under augusti månad ökade andelen enligt Pentti Mäkelä till 55 procent. $^{6}$

På massgraven restes år 1951 genom den kommunistiska organisationens Entiset punakaartilaiset - forna rödgardister försorg ett minnesmärke över dödsoffren. Den röda granitstenen försågs med en politiskt laddad text, som antyder att fångarna skulle ha dödats avsiktligt:

Till minne av dem som i klasskampen kämpade för folkväldet och föll offer för de vitas hämnd, avrättades och svältes ut, [...] Tusentals rödgardisters anda talar på denna kyrkogård till oss om de vitas grymhet och strömmar av blod. Den manar oss att vaksamt och oförfärat strida för folkväldet.

I själva verket finns det endast 13 belagda fall av dödade fångar $\mathrm{i}$ Dragsviklägret. Sex fångar avrättades efter flyktförsök den II-I4 juni, medan de övriga var enskilda incidenter, då vakter av någon anledning tappade besinningen och sköt. De resterande, omkring 3 oo० finländska män i sin bästa ålder, avled av andra orsaker. ${ }^{7}$

Hur gick det så här? Vilka faktorer låg bakom den okontrollerbara massdöden? Varför blev dödligheten i Dragsvik högre än i andra fångläger? Lägerdöden i Finland IgI8 har på ett allmänt plan varit föremål för en del nyare forskning, men orsakerna till dödligheten har förstås lägervisa särdrag. I den här artikeln granskas orsakerna till den exceptionellt höga dödligheten specifikt i Dragsviklägret. ${ }^{8}$

6. Pentti Mäkelä,”Tammisaaren täihelvetti”, Pertti Haapala \& Tuomas Hoppu (toim.), Sisällissodan pikkujättiläinen, Helsinki: WSOY 2009, s. 352 f; De dödas bok, Ba I4, Ekenäs krigsfångeläger-tvångsarbetsinrättnings arkiv, Riksarkivet, Helsingfors. En bevarad lista från I9I8 i SVL-överläkaren Max Björksténs papper anger totalantalet fångar i lägren i augusti som mest till 33 880. Av de där noterade I 605 dödsfallen stod Dragsvik för 763, d.v.s. 47 procent. Överläkarens brevkoncept I9I8, Dc I, Krigsfångeväsendets arkiv, Riksarkivet, Helsingfors.

7. Databasen för projektet Krigsdöda I9I4-I922, http://vesta.narc.fi/cgi-bin/db2www/ sotasurmaetusivu/main, (hämtad 20/4 2018); Sture Lindholm, Fånglägerbelvetet Dragsvik. Massdöden i Ekenäs 19I8, Ekenäs: Proclio 2017, s. I6o.

8. Dödligheten i de finländska fånglägren har på senare tid analyserats av bl.a. Pentti Mäkelä. Pentti Mäkelä, Vuosien I9I7-I9I9 kulkutaudit, espanjantauti ja vankileirika- 
Fånglägren I918 har inte alltid skildrats sakligt och faktabaserat i Finland. En del relativt nyligen publicerad facklitteratur som berör Dragsvik baserar sig i hög grad på fångars långt senare nedtecknade berättelser, vilka återges som objektiva fakta utan källkritiska överväganden. ${ }^{9}$ Föreliggande artikel strävar efter att sätta fånglägerdöden i sitt sammanhang och söka förklaringar till den humanitära katastrofen med hjälp av historiska forskningsmetoder.

\section{KAOTISK BÖRJAN}

Myndigheternas försök att i all hast upprätta ett omfattande system för att administrera fångfrågan blev en övermäktig uppgift i ett land som från tidigare saknade myndigheter av detta slag och dessutom nyss genomlidit ett inbördeskrig. Omständigheterna kring Dragsviklägrets tillkomst erbjuder en delförklaring till att lägret utvecklades till en katastrof.

Första gången omnämndes Ekenäs som en möjlig förvaringsplats för fångar i ett dokument daterat den 15 maj. Den 23 maj anlände 300 arbetsfångar från Sandhamn, jämte nödigt vaktmanskap, med uppgift att med taggtråd omgärda en del av det tidigare ryska militärområdet till ett fångläger. Arméns huvudintendentur fick motta en beställning på bland annat 35 kilometer taggtråd, 9 kilometer järntråd, 50 yxor och 50 spadar för omedelbar leverans till Ekenäs. ${ }^{10}$

Från huvudporten drogs en rät linje ner mot havsviken, och därifrån avskärmades ett ungefär 200 x 500 meter stort område österut, samt tydligen redan från början ett lite mindre område västerut. Mellan lägerhalvorna gick en bred gång, som i bägge ändarna hade konstant

tastrof: historiallisepidemiologinen näkökulma Suomen väestön korkeaan tautikuolleisuuteen, Suomen sotasurmat I9I4-22 -projekti, Valtioneuvoston kanslian julkaisusarja I6/2007, Helsinki: Valtioneuvoston kanslia 2007; Pentti Mäkelä, ”Epidemisiin sairauksiin menehtyneet", Lars Westerlund (toim.), Sotaoloissa vuosina I9I4-I922 surmansa saaneet: tilastoraportti, Valtioneuvoston kanslian julkaisusarja 10/2004, Helsinki: Valtioneuvoston kanslia 2004, s. 135-150.

9. Se t.ex. Tuulikki Pekkalainen \& Seppo Rustanius, Punavankileirit Suomessa I9I8: suomalainen murhenäytelmä, Helsinki: Tammi 2007.

Io. Major Verner Juvelius förslag till placering av ca 73 ooo fångar 15/5 I9I8, 56b, Etappstaben, Högkvarteret I918, Riksarkivet, Helsingfors; Inkvarterings- och transportavdelningens brevkoncept 2I/5 I9I8, De I, Krigsfångeväsendets arkiv, Riksarkivet, Helsingfors. 
soldatbevakning. Inom området fanns bland annat den stora kombinerade kyrkan-matsalen och fem tvåvåningskaserner i rödtegel. Invid den stora sandplanen på områdets östra sida låg en rad ekonomibyggnader i trä.

Redan den 29 maj anlände de första större fångtransporterna per järnväg till Dragsvik. Med transporten av 2055 fångar från Fredrikshamn anlände också den nyutnämnde lägerchefen Kaarlo Leisten. ${ }^{11}$ Fångarna anlände alltså till Dragsvik ungefär samtidigt som lägerledning, vaktmanskap och övrig personal. Någon komplett förteckning över vem som anlände varifrån och när existerar inte, för ingen hann göra upp en sådan i den kaotiska situationen vid lägrets etablering. Bristen på organisation och på såväl materiella som mänskliga resurser är en uppenbar bidragande orsak till att situationen i Dragsvik kom att utveckla sig så som den gjorde.

Fångtransporterna kom från olika delar av landet. Från Gamlakarleby anlände den 3 juni 804 fångar i 25 boskapsvagnar efter mer än ett dygns resa genom landet. Dagen innan tömdes fånglägret i Närpes och 344 fångar sändes till Ekenäs med tåg. Från Brahestad sändes den 3 juni en last på 478 fångar. Från Viborg anlände omkring 2 ooo fångar den 4 juni. ${ }^{12}$ Enligt den första officiella halvveckorapporten från Dragsvik, den 6 juni, hade lägret redan då 6850 manliga och 54I kvinnliga fångar. Som flest var fångarna den 24 juni: 8597 stycken. Den 20 juni hade de kvinnliga fångarna sänts till Sandhamn. ${ }^{13}$

Siffrorna måste dock tas med stor reservation. Till exempel borde enligt den officiella statistiken för den 20 juni 6r9 kvinnor ha funnits i Dragsvik, men vid avfärden från lägret var det 644 kvinnor som steg på tåget. Likaså visar rapporten från Dragsvik den 5 september

II. Leistens brev till SVL-chefen 3I/8 I9I8, nr I387, Ec 2, Krigsfångeväsendets arkiv, Riksarkivet, Helsingfors.

I2. Inkvarterings- och transportavdelningens brevkoncept, De I, Krigsfångeväsendets arkiv, Riksarkivet, Helsingfors; Paavolainen, Vankileirit Suomessa, s. 265; Pekka Railo har skrivit om fångarna från Gamlakarleby i ett manuskript som lämnades in till Arbetararkivet i Helsingfors I96I men som publicerades först 20II. Pekka Railo, Valkoisten vankina. Päiväkirja Kokkolan ja Tammisaaren punavankileiriltä I9I8, Pekka Tuomikoski (toim.), Helsinki: Minerva 20 II.

I3. Halvveckorapporterna från Dragsvik, Ec 4, Krigsfångeväsendets arkiv, Riksarkivet, Helsingfors. Eftersom det inte dog några kvinnliga fångar i Dragsvik behandlar jag dem inte närmare i den här artikeln. 
att antalet fångar på tre dagar plötsligt minskade från 2 98I till 2 I2I. Skillnaden på 860 kan inte förklaras av de 69 avlidna och I23 frigivna (samt $\mathrm{r} 3$ nytillkomna), men får sin förklaring i en anteckning av vicecheferna: "Korrigerat på basen av namnupprop." ${ }^{14}$ De tidigare uppgivna sifforna baserade sig uppenbarligen på subtraktion av antal döda och frigivna från sifforna i tidigare rapporter, inte på en faktisk räkning av fångarna.

En ibland förbisedd faktor i analysen av dödligheten i de finländska fånglägren är skillnaderna mellan olika fångkategorier. Från Karelen och Fredrikshamn kom personer som tagits till fånga i krigets slutskede, antingen rödgardister som kapitulerat eller civila på flykt undan de vita och tyskarna. Fångarna från Österbotten var däremot till stor del olika aktivister inom arbetarrörelsen, vilka hade suttit internerade i fångläger redan i upp till fyra månader, och var sjuka, undernärda och försvagade redan vid ankomsten. I till exempel Gamlakarleby hade omkring $\mathrm{I}$ ooo fångar suttit internerade i några trångbodda skolhus. Efter mer än tre månader där hade smittsamma sjukdomar börjat spridas bland dem. I början av juni tömdes lägret och kvarvarande 802 fångar - friska såväl som sjuka - sändes i stängda tågvagnar genom landet ner till Ekenäs. Ankomsten av sjuka fångar till Dragsvik blev ödesdiger. ${ }^{15}$

När fångarna anlände fylldes kasernerna på några dagar. Flera fångar har vittnat om hur vakterna i början gav upp försöken att organisera fångarnas ankomst. Var och en fick söka sig en sovplats så gott det gick, och snart var alla tänkbara utrymmen fullpackade med människor. Många sov direkt på betonggolvet eller försökte hitta

I4. Halvveckorapporterna från Dragsvik, Ec 4, Krigsfångeväsendets arkiv, Riksarkivet, Helsingfors.

I5. Hillevi Toiviainen, Gamlakarleby stads historia. Del IV: tidsskedet 1879-1945, Karleby: Karleby stads förlag 200I, s. I7I ff, 337 f; Bland fångarna i Gamlakarleby fanns intellektuella, såsom lärare och journalister från olika delar av landet, vilka senare skriftligen skildrat förhållandena också i Dragsvik. Förutom Pekka Railos Valkoisten vankina kan t.ex.läraren Vilho Korhonens anteckningar nämnas. Vilho Korhonen, Muistiinpanoja, TMT: 262/405I, Arbetararkivet, Helsingfors; Vilho Korhonen, Wankila muistelmia, 323:2, I918 års arkiv, Arbetararkivet, Helsingfors. 
en egen vrå på en vind eller ute i något skjul. Helt oorganiserad kan ankomsten ändå inte ha varit. Kvinnorna bevakades noga och inkvarterades separat från männen i en egen kasern, och lasten av magsjuka fångar från Närpes isolerades i en egen kasern. ${ }^{16}$

Det finns få bevarade skildringar från lägerledningens håll som kunde kasta ljus över läget vid lägrets organisering. Den till Ekenäs utsända rannsakningschefen Heikki Borenius klagade dock den I juni över att man i Dragsvik varken organiserat några kanslier eller fått igång ett kortsystem för registrering av fångarna, trots att ett stort antal fångar redan anlänt. ${ }^{17} \mathrm{Av}$ ett brev den ro juni av SVL-chefen Juvelius till lägerchefen Leisten framgår att kansliet i Ekenäs inte svarade i telefonen, och att arbetsfördelningen mellan personalen var så oklar att de berörda cheferna inte visste vad var och en ansvarade för. ${ }^{18}$ Först den II juni utnämndes en sekreterare i kansliet: den 49-årige löjtnanten Werner Gräsbeck. ${ }^{19}$

\section{MATHÅLLNINGEN EN UTMANING}

Att förse de mer än 75 ooo fångarna i landet med mat blev en stor utmaning för krigsfångeväsendet SVL. Kriget I9I8 hade inte gjort den redan från tidigare prekära livsmedelsförsörjningen lättare, och ransoneringen av livsmedel fortsatte sommaren I9I8. Speciellt tillgången på brödsäd var ringa; världskriget pågick fortfarande och ententeländernas handelsblockad mot Tyskland gällde under rådande förhållanden också Finland. Finland importerade 70o ton spannmål från Tyskland sommaren I9I8 - men behovet var det tiodubbla. ${ }^{20}$

SVL:s ledande män slog vid ett möte i Helsingfors den 2I maj fast hurdan mat fångarna skulle serveras i lägren. En dagsranson på I 500 kalorier ansågs vara den minimimängd som en människa behövde:

16. Railo, Valkoisten vankina, s. 239-247; Railo uppger kvinnornas antal till runt 800.

I7. Anlända brev, $\mathrm{nr}$ 24, Ea I, Ekenäs krigsfångeläger-tvångsarbetsinrättnings arkiv, Riksarkivet, Helsingfors.

I8. Ibid., nr 55 .

19. Listor över personal, Gc 9, Krigsfångeväsendets arkiv, Riksarkivet, Helsingfors.

20. Marjaliisa Hentilä \& Seppo Hentilä, Saksalainen Suomi, Helsinki: Kustannusosakeyhtiö Siltala 2or6, s. 223 ff; Paavolainen, Vankileirit Suomessa, s. I7o. 
Bröd

Smör

Strömming

Klippfisk

Fett

Linfrö

Rågmjöl

Kalorimängd dag I

$75 \mathrm{gr}$

$25 \mathrm{gr}$

$200 \mathrm{gr}$

$200 \mathrm{gr}$

$20 \mathrm{gr}$

$20 \mathrm{gr}$

$5 \mathrm{gr}$

I 524 dag II

$75 \mathrm{gr}$

$25 \mathrm{gr}$

sill $200 \mathrm{gr}$

kött $200 \mathrm{gr}$

$30 \mathrm{gr}$

$30 \mathrm{gr}$

Io gr

surkål $300 \mathrm{gr}$

I 474

Vidare beslöts om ett förbud för fångarnas anhöriga att hämta mat till lägren. Förbudet motiverades både med den rådande livsmedelsbristen och med att de införda paketen kunde innehålla vapen för ett eventuellt fånguppror. ${ }^{21}$

Det var enorma mängder mat som måste skaffas fram för fångarnas behov. Redan för en daglig brödranson på 75 gram per fånge måste SVL:s intendentur skaffa fram 180 ton bröd i månaden. Månadsbehovet av smör var 60 ton och till exempel av sill och strömming 240 ton var. ${ }^{22}$ I praktiken visade det sig omöjligt för lägren att följa rekommendationerna. De flesta beskrivningarna av mathållningen i Dragsvik baserar sig på en lista som enligt Pekka Railo ska ha gjorts upp av en fånge den 2-26 juli. Listan har återgetts av både Jaakko Paavolainen och Jouni Eerola. Enligt listan bestod fångarnas frukost vanligen av en halv sill och 75 gram bröd, vilket enligt Railos uppskattning innehöll 3I5 kalorier. Vissa dagar gavs endast 35 gram bröd, och i mitten av månaden blev fångarna helt utan bröd i fyra dagar. På morgonen den 20 juli skall fångarna ha serverats endast en halv sill och inget annat. Middagen bestod sedan av antingen torsksoppa eller rotsoppa, medan köttsoppa serverades endast tre av dessa tjugofem dagar. ${ }^{23}$

2I. Protokoll från möte i Helsingfors på initiativ av SVL:s intendentur 2I/5 I9I8, $\mathrm{C}_{\mathrm{I}}$, Krigsfångeväsendets arkiv, Riksarkivet, Helsingfors.

22. Intendenturens brevkoncept $\mathrm{I} 8 / 6$ I9I8, Dd I, Krigsfångeväsendets arkiv, Riksarkivet, Helsingfors.

23. Railo, Valkoisten vankina, s. 275. Paavolainen, Vankileirit Suomessa, s. 216; Eerola, Ekenäs I9I8, s. I7. I det sistnämnda verket, s. I4, citeras också fången Lauri Salmis hågkomster i Folkets arkiv. Enligt Salmi var det före midsommar som brödet uteblev, men han överdrev längden på den brödlösa perioden: "Under två veckors 
Det finns ingen orsak att betvivla de uppgivna mängderna, men den angivna tidpunkten är felaktig. På basen av andra källor är det uppenbart att Railo - när han skrev sitt manuskript ett halvsekel senare - har misstagit sig. Det var inte den I7-20 juli fångarna blev utan bröd, utan en knapp månad tidigare. Skribenten tycks ha börjat göra upp listan vid sin ankomst till lägret, sannolikt den 4 juni, och inte den 2 juli.

Att det var strax före midsommar som livsmedelsbristen blev akut i Dragsvik visar lägerläkaren Toivo Elliläs brev den 20 juni: "Maten är slut. Idag delades endast ut $35 \mathrm{gr}$ bröd till frukosten. Hela kalorimängden idag är högst 800 (åttahundra). Igår ca I ooo. Imorgon delas inte alls ut något bröd." ${ }^{4}$ Tydligen var orsaken till den akuta brödnöden byråkratiskt slarv hos intendenturen. Samma dag telegraferade lägerchefen Leisten till Helsingfors:

Den 30 maj beställde ekonomichefen $[. .$.$] av intendenturen 30$ ooo $\mathrm{kg}$ rågmjöl, vilken beställning trots löften förblev ouppfylld. Den 7 juni förnyade ekonomichef Palmgren personligen beställningen men när han på nytt den $\mathrm{I} 7$ juni besökte intendenturen fick han svar att beställningen inte finns där. När man letade fann man den bland papperslapparna. ${ }^{25}$

Den 22 juni meddelade intendenturens kostavdelning att den sänt 8 ooo kg havremjöl till Ekenäs och beordrat leverans av 300 kärl sill, men ignorerade alla antydningar om bortslarvade beställningar och gav i stället ekonomichefen Erik Palmgren en tillrättavisning: "Som redan tidigare meddelats Er måste beställningarna oundvikligen göras i god tid, och inte som nu i allra sista stund, för det är helt omöjligt att skicka leveranser med så här kort varsel."

Samma dag meddelade intendenturen de olika fånglägren att rågmjölet tagit helt slut i landet, varför de i fortsättningen måste nöja

tid erhöll fångarna inget annat än en halv sill per dag. Bröd eller någon annan föda fick de inte alls.”

24. Toivo Ellilä till överläkaren 20/6 I9I8, Brev till överläkaren, nr 77, Ee I, Krigsfångeväsendets arkiv, Riksarkivet, Helsingfors.

25. Leistens telegram till SVL-chefen $20 / 6$ I9I8, Ef 2, Till intendenturens kostavdelning anlända brev, Krigsfångeväsendets arkiv, Riksarkivet, Helsingfors. 
sig med linfrö, havremjöl eller finfördelad klippfisk. Men samtidigt beordrades också lägren, paradoxalt nog, att höja fångarnas matranson med 300 kalorier, så att en icke-arbetande fånge dagligen skulle tilldelas I 800 och en arbetsfånge 2300 kalorier. $^{26}$

Den dagen ordern gavs serverades inget bröd alls i Dragsvik, och också de andra livsmedlen var på upphällning. Ekonomichefen Palmgren hade den 22 juni bara kvitterat mottagandet av en vagnslast salt. Följande dag anlände $2250 \mathrm{~kg}$ smör och 6 ton linfrö. ${ }^{27}$ Efter de brödlösa dagarna kunde man i Dragsvik först servera linfröbröd, och efter den ovannämnda havrelastens ankomst den sedermera så beryktade "piikkimurikkan". Havren, som på den tiden främst sågs som kreatursfoder, maldes samman med sådor och skal och bakades till en stickig brödkaka. Läkarna betecknade brödet som hälsovådligt. ${ }^{28}$

Krigsministern Wilhelm Thesleff medgav den 5 juli, i samband med en interpellationsdebatt i lantdagen rörande situationen i fånglägren, att fångarnas näringstillförsel inte varit tillräcklig, men förklarade att den allvarliga livsmedelsbristen i hela landet medförde att en stor del av folket "åt bark istället för bröd" i väntan på den nya skörden. Näringsbristen åstadkom ett allmänt sjukdomstillstånd i landet, uppgav ministern, som konstaterade att epidemiska sjukdomar var i rörelse och människor var allmänt svaga och utan motståndskraft. ${ }^{29}$ Hur den samtida verkligheten tedde sig ute i lägren framgår av SVLöverläkaren Björksténs rapporter. Till exempel slog lägerläkaren Karl Magnus Gadd i Viborg den 8 juli larm om skriande matbrist där:"Kan ingenting göras får man lof att låta en eller annan svälta ihjäl, men jag kan icke känna mig till freds med att ofta höra om inspektioner, som gifvit tillfredsställande resultat, i strid mot uppenbara fakta." ${ }^{30}$

Efter midsommartiden kan man ändå märka en förbättring $\mathrm{i}$ mathållningen i Dragsvik. Den 25 juni sände intendenturen I2,5 ton sopprötter och I80 fat med nästan 28 ton sill till Ekenäs. Fyra dagar

26. Intendenturens brevkoncept, Dd I, Krigsfångeväsendets arkiv, Riksarkivet, Helsingfors.

27. Ibid.

28. Paavolainen, Vankileirit Suomessa, s. I82-I86; Anlända brev nr I60/1918, Ea 3, Ekenäs krigsfångeläger-tvångsarbetsinrättnings arkiv, Riksarkivet, Helsingfors.

29. Paavolainen, Vankileirit Suomessa, s. 302-303.

30. Björksténs rapport 8/7 I9I8, Dokument anlända till VATO, Ea I.I-I.2, Krigsfångeväsendets arkiv, Riksarkivet, Helsingfors. 
senare kom ytterligare 300 silltunnor och meddelandet att sex ton linfrömjöl för lägrets behov höll på att malas i Dickursby. Också 509 fat nyanländ surkål sändes till Dragsvik, som därmed hade mer än tillräckligt av den varan under resten av sommaren. ${ }^{31}$ Kvaliteten på kålen var dock inte den bästa; redan den 15 juli rapporterades att innehållet i en del av tunnorna var helt förfaret, och att tunnorna hade torkat så att de inte höll vatten. Sedan 207 nötkreatur den Io juli anlänt till Dragsvik, var dock tillgången på färskt kött tryggad. ${ }^{32}$

En lättnad för fångarna var att förbudet mot matpaket utifrån upphävdes den 4 juli. SVL:s ekonomiska granskare Juho Kaartotie noterade i början av augusti att paketavdelningen i Dragsvik då varje dag fick ta emot mellan I ooo och I 500 mat- och klädpaket, och att en stor mängd fångar då inte alls gick till lägrets matutdelning. Den stadgade kalorimängden i lägret hade "snarare underskridits än överskridits", och inte ens de sjuka hade erhållit I 700 kalorier per dag. Men mathållningen var uppenbart då på väg mot det bättre. Livsmedel fanns i förråden och brödet var numera till och med av bättre kvalitet än det man fick köpa i Helsingfors. Av det serverades I40 eller 200 gram per dag, medan smörransonen var 25 gram. Kött serverades normalt varannan dag, men någon färsk fisk hade lägret dittills inte kunnat servera, noterade Kaartotie. ${ }^{33}$

Också docent Carl Tigerstedt - professor Robert Tigerstedts son kunde vid sin inspektion den 23 augusti konstatera att man i Dragsvik vidtagit” alla möjliga åtgärder för att förbättra den vid detta fångläger utspisade kosten”. Surkål hade inte delats ut på nästan en månad, och serveringen av den hatade klippfisken hade kraftigt minskats. "Kosten har sålunda hufvudsakligen bestått af spannmål, torkade rotfrukter, sill, kött och smör”, rapporterade Tigerstedt, som också gav en trovärdig förklaring till att så många fångar just i Dragsvik betraktade klippfisksoppan som vedervärdig. Problemen hade uppstått vid urlakningen av den torkade fisken som lades i perforerade lådor i

3I. Intendenturens brevkoncept, Dd I, Krigsfångeväsendets arkiv, Riksarkivet, Helsingfors.

32. Ibid.; om boskapens ankomst: Brev till intendenturen, $\mathrm{nr}$ 55/r9I8, Ef 2, Krigsfångeväsendets arkiv, Riksarkivet, Helsingfors.

33. Juho Kaartoties rapport från granskning i Ekenäs 2/8 I9I8, Dokument anlända till VATO, Ea 4, Krigsfångeväsendets arkiv, Riksarkivet, Helsingfors. 
strandvattnet i ett par dygn och där skvalpades om. Att denna metod i och för sig är fullt effektiv, kan icke betviflas, men då fisklådorna emot order nedsänkts i det några decimeter djupa strandvattnet, blef resultatet att fisken delvis hunnit undergå förruttnelse." ${ }^{34}$

I överlevande fångars hågkomster påstås ofta att segrarna med flit försökte svälta ihjäl fångarna. Påståendet har föga stöd i det samtida källmaterialet. Svälten var inte avsiktlig eller planlagd. Visserligen bidrog det omtalade paketförbudet till katastrofen, men den bestämmelsen bottnade i myndigheternas oro för den allmänna livsmedelsförsörjningen i landet och i tron på att fångarna skulle kunna bespisas genom fängelsemyndigheternas försorg.

Frågan om vem som bar ansvaret för de uppenbara problemen i Dragsvik bollades mellan de olika nivåerna i fånglägersystemet redan sommaren 1918. Låg ansvaret hos intendenturen, som inte kunde förse lägren med tillräckliga mängder mat, eller hos lägren, som inte sett till att göra beställningar eller kunnat se till att fångarna faktiskt fick sina stipulerade ransoner?

Bägge nivåerna tenderade att skylla på varandra. Som exempel kan ges en ordväxling mellan intendenturen i Helsingfors och ekonomichefen Palmgren i Dragsvik. Denne blottade sin ouppmärksamhet, när han den 28 juni frågade intendenturens kostavdelning var en utlovad last av saltkött dröjde. Dragsvik hade tydligen inte noterat intendenturens meddelande tre veckor tidigare att saltköttet var slut i statens lager, varför lägren i stället erhöll klippfisk.

"Det skulle vara full orsak för er att noggrannare bekanta er med innehållet i de brev ni får", svarade intendenturen, som redan den 7 juni uppmanat fånglägrens ekonomiföreståndare att komma överens om leverans av färsk fisk med de fiskbörser som nyligen upprättats i landet. Fisk skulle sedan serveras minst två dagar i veckan. ${ }^{35}$ Ekenäs hade dock inte gjort några som helst ansträngningar för att dryga ut kosten med färsk fisk. Palmgren förklarade sig för intendenturen den 26 juni:

34. Carl Tigerstedts rapport från inspektionen 23/8 I9I8, Anlända brev, Ea 3, Ekenäs krigsfångeläger-tvångsarbetsinrättnings arkiv, Riksarkivet, Helsingfors.

35. Intendenturens brevkoncept, Dd I, Krigsfångeväsendets arkiv, Riksarkivet, Helsingfors. 
Det har hittills varit omöjligt att transportera större mängder färsk fisk från järnvägsstationen till fånglägret, delvis därför att de arbetskärror som vi beställde från Krigsfångeväsendets intendentur redan den 5 dennes inte levererats trots många förfrågningar och förnyade beställningar, delvis av den orsaken att de 50 ordningsmän som major Juvelius lovade redan den 12 dennes fortfarande inte är här och av den anledningen har vi inte tillräckligt med ordningsmän för att transportera matvarorna.

Men, tillade ekonomichefen, i Ekenäs hade man ännu inte varit i så stort behov av fisk, "eftersom vi ännu tillsvidare kunnat dela ut köttsoppa var tredje dag". ${ }^{36}$

Eftersom dödligheten i Ekenäs i augusti var betydligt högre än i de övriga fånglägren, kunde man anta att matsituationen i andra läger var bättre. Så verkar det dock inte ha varit. Av Carl Tigerstedts rapporter från granskningarna av fånglägren i Villmanstrand och Viborg i slutet av augusti framgår det att läget där faktiskt tedde sig värre än i Ekenäs.

I Villmanstrand var tillredningen av maten i alla avseenden otillfredsställande. Saltet urlakades för dåligt, rotfrukterna var undermåliga och kosten onödigt enformig. Fånglägret erhöll bara ı-30 liter mjölk om dagen, vilket för sjukhusets I50 patienter var alldeles för lite. Fångarna i Villmanstrand saknade ännu i augusti matkärl:"sjuka som friska erhåller sin kost i näverrivor, af takrännor tillredda skålar, i alla möjliga bleckburkar." I Viborg befanns Markovilla-sjukhuset vara i förstklassigt skick, men de födoämnen som skickades dit från centralkasernen var kvalitativt undermåliga och mängden otillräcklig. I själva fånglägret i Viborg kokades maten inte tillräckligt länge och råvaran urlakades för lite. Faten, som klippfisken urlakades i, innehöll förskämd vara. I Viborg uppdagades att fängelsedirektören hade negligerat myndigheternas uppmaning att låta fångarna motta

36. Palmgren till intendenturens kostavdelning, nr I5, Ef 2, Krigsfångeväsendets arkiv, Riksarkivet, Helsingfors. 
matförsändelser. Chefen vägrade även nu att lätta på förbudet; för det krävdes en skriftlig order av Krigsfångvårdsstyrelsen. Tigerstedt efterlyste en undersökning om varför "en för fångarnas lif och hälsa synnerligen betydelsefull order på detta sätt icke blifvit åtlydd". ${ }^{37}$ Eftersom dödligheten i de här beskrivna fånglägren var betydligt lägre än i Ekenäs, vore det lätt att dra slutsatsen att den främsta orsaken till massdöden i Ekenäs inte var mathållningen. Men synbarligen fick matbristen i Dragsvik tidigare under sommaren särskilt ödesdigra konsekvenser för fångarna där. Robert Tigerstedt drog i sin tidigare citerade rapport slutsatsen:

Otillräcklig föda och svåra, genom födans och vattnets olämpliga beskaffenhet framkallade digestionsrubbningar måste betecknas såsom de väsentligaste orsakerna till den stora sjuklighet och dödlighet, som råder i fånglägret. ${ }^{38}$

\section{UTRYMMESBRIST OCH SANITÄRA OLÄGENHETER}

Faktorer man inte kan bortse från vid en analys av dödligheten i Dragsvik är trångboddheten och de usla sanitära förhållandena. När fångtransporterna anlände till Dragsvik fylldes kasernerna, som de ryska trupperna enligt många vittnesmål lämnat i bedrövligt skick, på ett förhållandevis okontrollerat sätt. Snart var lägret fullt. ”Till att börja med bor fångarna alldeles för trångt, i en del kaserner med knappast ens $3 \mathrm{~m}^{3}$ luft per person. Smutsen i kasernerna är förskräcklig. Varenda fånge har klädlöss och dessa kan inte fås bort innan fängelsets bastu fătts i skick," skrev lägerläkaren Ellilä, som redan den I5 juni betecknade de hygieniska förhållandena i Dragsvik som "närmast olidliga" och varnade för att smittsamma sjukdomar skulle spridas bland fångarna om inte olägenheterna åtgärdades. ${ }^{39}$ Ellilä vädjade om att nya fångar inte skulle sändas till Dragsvik innan man byggt

37. Oregistrerat brev till överläkaren, Ee I, Krigsfångeväsendets arkiv, Riksarkivet, Helsingfors.

38. Robert Tigerstedt, "Rapport ...” 5/8 I9I8, Brev till överläkaren, nr 2II, Ee I, Krigsfångeväsendets arkiv, Riksarkivet, Helsingfors.

39. Toivo Ellilä till överläkaren I5/6 I9I8, nr 61, Ee I, Krigsfångeväsendets arkiv, Riksarkivet, Helsingfors. 
nya baracker och de hygieniska förhållandena var "på en någorlunda tolerabel nivå”. Men fem dagar senare fortsatte nya fångar att anlända. En ny last på 900 fångar väntades, skrev Ellilä den 20 juni: "Som jag redan tidigare meddelat så finns här inte någon plats där de kunde placeras. Man har inte börjat bygga några baracker, trots alla uppmaningar, vädjanden eller order. Ledaren skyller på behovet av arbetsledare och brist på material och verktyg." ${ }^{40}$ De 876 nya fångar som anlände från Åbo placerades i några stall- och liderbyggnader. "Åbo-avdelningen" rymde snart drygt tusen människor.

De sanitära förhållandena i Dragsvik var katastrofala i juni. Latrinerna i de ryska kasernerna i Finland var byggda i samma stil som i Riihimäki, där en militärläkare i oktober I9I8 beskrev situationen. Från latrinerna i bägge våningarna i kasernernas ändar ledde ett järnrör rakt ner till källaren, till en cistern som stod i direkt förbindelse med resten av kasernen genom de öppna rören och locklösa stolarna. De hygieniska olägenheterna var påtagliga. ${ }^{41}$ I Dragsvik-kasernerna stockade sig latrinerna genast."Kasern B övre våningens brunn stockad och urinen rinner ut över allt”, rapporterade fångsanitären Kaarle Nordlund till lägerläkaren Ellilä den 27 juni, och ansåg att latrinen i västra delen av den stora kasernen borde stängas och dörren spikas fast, eftersom den inrättningen var "helt omöjlig att använda". ${ }^{42}$ I lägret uppfördes visserligen andra avträden, tillfälliga öppna gropar med en stång över ett djupare dike. Att under sommarmånaderna på ett hygieniskt sätt organisera tömningen av dem är ett omvittnat problem från många läger, liksom stanken som omgav lägret. Att problemen i Dragsvik var exceptionella antyds av att VATO-chefen överste Herman Wärnhjelm den 16 juli beordrade ledningen att å det snaraste göra något åt de hygieniska förhållandena:

40. Toivo Ellilä till överläkaren 20/6 I9I8, nr 77, Ee ı, Krigsfångeväsendets arkiv, Riksarkivet, Helsingfors.

4I. Sanna Ihatsu, Dragsvikin asuinrakennusten uudelleenkäytön selvitys, diplomityö, arkkitehtiosasto, Teknillinen korkeakoulu 2003, s. 8I.

42. Kaarle Nordlunds rapport till överläkaren $27 / 6$ I9ı, Ba I4, Ekenäs krigsfångelägertvångsarbetsinrättnings arkiv, Riksarkivet, Helsingfors. Nordlund var senare stadsdirektör i Tammerfors I929-I943. 
Speciellt bör avträdena och klosetterna i byggnaderna hållas i oklanderligt skick och kalkas ordentligt samt sittbrädena tvättas med såpa. Avträdena bör, vid behov och möjlighet, avskiljas med taggtråd så att stängslet går på 15-20 meters avstånd från de omgivande byggnaderna, och om möjligt bör avträdena städas nattetid. ${ }^{43}$

Till de värsta olägenheterna i Dragsvik hörde bristen på vatten. Det ryskbyggda vattentornets kapacitet räckte inte till för att förse de drygt 8 ooo fångarna ens med dricksvatten, än mindre något tvättvatten. "Vattnet tar alltid slut kring 4-5-tiden på eftermiddagen. Detta tvingar fångarna att försöka stilla sin törst genom att dricka vatten i diken och små pölar”, skrev Ellilä den I5 juni. $^{44}$ Den 2 I juni bad lägerchefen Leisten SVL-chefen om hjälp för att huvudintendenturen faktiskt skulle sända det beställda vattenledningsmaterialet till Dragsvik, eftersom fångarnas antal ökade för var dag och "här råder en kännbar vattenbrist". ${ }^{45}$ Vattenhanteringen sågs som en hälsorisk. Ur granskningsrapporter från augusti framgår att lägerläkaren nog gett order om att allt vatten skulle kokas, vilket dock fortfarande inte lät sig göras eftersom det i Dragsvik ännu varken fanns tillräckligt med kokkärl eller hästar för att transportera vattnet. ${ }^{46}$

De flesta fångar gick i samma kläder som de gått i hela våren, och de hade på grund av vattenbristen inte haft möjlighet att tvätta ens underkläderna. Fångarna fick dock ta emot klädpaket, och en del fångar erhöll den vägen klädesplagg, som också var till nytta i den byteshandel som förekom. I fånglägrets eget lager var det synnerligen ont om kläder, och de få persedlar som kom till lägret försvann ofta på okända vägar. Först under andra hälften av juli fick fångarna möjlighet att tvätta sina kläder, då det på gårdsplanen utanför sjukhuskasernen upprättades en tillfällig tvättstuga. ${ }^{47}$

43. Anlända brev nr I97/I918, Ea I, Ekenäs krigsfångeläger-tvångsarbetsinrättnings arkiv, Riksarkivet, Helsingfors.

44. Ellilä till överläkaren, nr 6r, I5/6 I9ı8, Ee I, Krigsfångeväsendets arkiv, Riksarkivet, Helsingfors.

45. Brevkoncept, nr 23, Da I, Ekenäs krigsfångeläger-tvångsarbetsinrättnings arkiv, Riksarkivet, Helsingfors.

46. Kaartoties rapport från granskning i Ekenäs 2/8 I9I8, Dokument anlända till VATO, Ea 4, Krigsfångeväsendets arkiv, Riksarkivet, Helsingfors.

47. Förhör med sjuksköterskan Matilda Hjon, direktionens protokoll 4/2 I9I9, Ca I, 
Till ödets ironi hör att Dragsvik ligger vid stranden av Finska viken. Men trots att direktiven från Helsingfors den 6 juni lydde: "Mot stranden skall dras en öppning $\mathrm{i}$ taggtrådsstängslet så att fångarna kan gå och tvätta sig”" ${ }^{\prime 4}$, gjordes ingenting åt den saken under hela juni månad, trots att stranden låg bara på några tiotal meters avstånd. Källorna förtäljer inte varför, men det är sannolikt att den uttalade bristen på pålitligt vaktmanskap gjorde att ledningen $\mathrm{i}$ juni inte tog risken att låta fångarna gå ner till vattnet. Först i slutet av juni utvidgades lägerområdet ända ner till stranden. Vid det laget var fångarnas tillstånd så försvagat att många av dem inte längre brydde sig om att gå dit. Inspektorn Kaartotie noterade den 2 augusti att fångarna var täckta av ett tjockt lager smuts: "När fånglägret ligger alldeles vid stranden skulle man tro att alla skulle ha en möjlighet att åtminstone tvätta ansiktet, men de vill inte utnyttja varken det tillfället eller att gå och simma." ${ }^{49}$

De hygieniska förhållandena, liksom trångboddheten, förefaller enligt Jaakko Paavolainens undersökningar ha varit ungefär lika eländiga i många andra läger. Likadant var det med lössens ymniga förekomst. De smutsiga plaggen erbjöd utmärkta hemvister för löss, som förökade sig i explosiv takt och snart blev ett allt värre gissel för fångarna. Enligt Paavolainen kunde man just i Ekenäs och på Sveaborg ordna badmöjligheter, eftersom lägren låg vid vattnet, men han tycks inte ha noterat att det i Ekenäs dröjde ända till juli innan den möjligheten i praktiken gavs. Bastubad, med därtill hörande avlusning av kläder, erbjöds i början av juli omkring 500 fångar dagligen på Sveaborg, men i Dragsvik hade avlusningsinrättningen inte fătts i skick ännu den 9 juli..$^{50}$ "Varenda fånge har klädlöss och dessa kan inte fås bort innan fängelsets bastu fåtts i skick", skrev läkaren Ellilä redan den 15 juni. Nagon möjlighet till bastubad gavs dock inte $\mathrm{i}$ Dragsvik under början av sommaren. Funktionärerna hade en bastu

Ekenäs krigsfångeläger-tvångsarbetsinrättnings arkiv, Riksarkivet, Helsingfors.

48. Anlända brev, nr 48, Ea I, Ekenäs krigsfångeläger-tvångsarbetsinrättnings arkiv, Riksarkivet, Helsingfors.

49. Kaartoties rapport från granskning 2/8 I918, Dokument anlända till VATO, Ea 4, Krigsfångeväsendets arkiv, Riksarkivet, Helsingfors.

50. Paavolainen, Vankileirit Suomessa, s. 270-275; Överläkarens brevkoncept, nr 88, Dc I, Krigsfångeväsendets arkiv, Riksarkivet, Helsingfors. 
till sitt förfogande i en bageribyggnad, men dit släpptes inte vanliga fångar. Däremot snickrade en företagsam fånge från Savolax ihop en fältbastu av ett par trälådor på den stora sandplanen. Inuti den fanns en liten ugn och en ungefär halvannan meter lång bänk, där två män fick plats. För ett sådant bastubad debiterade fången en mark..$^{51}$

Senast i början av augusti hade också Dragsvik fått en avlusningsinrättning, där man hettade upp kläder. Invid den fanns en bastu, där fångarna gavs möjlighet att tvätta sig med varmt vatten, även om själva bastun inte var uppvärmd. Avlusningsinrättningen användes tydligen främst för fångar som skulle friges. Tvättrummet intill var ännu i början av september enligt Carl Tigerstedt helt kallt:

Under sådana omständigheter är det alldeles naturligt att fångarna så mycket som möjligt undvika att utsätta sig för obehaget att frysa under den timme aflusningen af deras kläder tager i anspråk. ${ }^{52}$

I september inleddes arbetet på en ny bastu med två avdelningar för 50 man. Den stod färdig i början av oktober och därmed kunde 400-500 man varje dag erhålla bastubad. ${ }^{53}$ De förbättrade hygieniska förhållandena i Dragsvik märktes direkt också i form av sjunkande dödlighet.

\section{TUKTHUSFÅNGARNA - DE VÄRST UTSATTA?}

När statsförbrytelsedomstolarna i Ekenäs den ro juli kom igång med sin verksamhet, var fånglägerkatastrofen redan ett faktum. Det insåg också myndigheterna. Redan den 20 juni stadfästes lagen angående villkorlig straffdom, vilken gjorde det möjligt att försätta majoriteten av de röda fångarna på fri fot genast då de fått sin dom. ${ }^{54}$ Men för dem som dömdes till längre fängelsestraff måste fånglägren inrätta

5I. Ellilä till överläkaren I5/6 I9I8, nr 6I, Ee I, Krigsfångeväsendets arkiv, Riksarkivet, Helsingfors; Railo, Valkoisten vankina, s. $254 \mathrm{f}$.

52. Carl Tigerstedt till SVL-chefen 7/9 I9I8, Anlända brev, nr 349, Ea 3, Ekenäs krigsfångeläger-tvångsarbetsinrättnings arkiv, Riksarkivet, Helsingfors.

53. Uno Töttermans rapport I7/IO I918, Ea I42, Fångvårdsstyrelsens kanslis arkiv, Riksarkivet, Helsingfors.

54. Lasse Vihonen, Valtionrikosoikeudet Suomessa r9r8, Pro gradu -tutkielma Suomen historiassa, Helsingin yliopisto I977, s. 42. 
regelrätta fängelseavdelningar. Tukthusfångarna skulle hållas strikt åtskilda från de andra fångarna, de dömdas skjortryggar försågs med två parallella, trettio centimeter långa och fem centimeter breda vita tygstycken, och deras kaserner skulle avskiljas med taggtrådsstängsel från det övriga lägret. ${ }^{55}$

I Dragsvik hade kasernen med de kvinnliga fångarna mycket lägligt tömts. Den gjordes nu om till högvakt, där speciellt viktiga fångar förvarades. Också Närpeskasernen och den östra långa kasernens övre våning togs $\mathrm{i}$ bruk för förvaring av tukthusfångar. Av de I I54 domslut som domstolsavdelningarna i Ekenäs avkunnade under juli var exakt 700 ovillkorliga. Således trängdes redan den I augusti 700 tukthusfångar i de för dem avskilda kasernerna. En månad senare hade sammanlagt 4 ooo fångar fått sin dom, och I 600 fătt lämna Dragsvik, som därmed hyste runt 2400 tukthusfångar. ${ }^{56}$

För tukthusfångarna började en verkligt helvetisk tid i de trångbodda logementen. "I dessa rum med sin alldeles otillräckliga luftkub och golvyta hava fångarna sina viloplatser dels på golvet, dels på träbritser i två, tre och fyra étager, ja, åtminstone i ett logement förkomma fem rader britser över varandra”, skrev Robert Tigerstedt, som noterade avsaknaden av sängkläder ännu i slutet av juli. Fångarna fick inte heller under nätterna gå ut för att göra sitt tarv, "utan i och för uppsamlandet av tarmuttömningarna placeras en så i rummet. Det behöver ju icke någon vidare utläggning för att klargöra, huru förpestad luften här under nattens förlopp småningom måste bliva." ${ }^{57}$ Även i sin följande rapport en knapp månad senare betecknade Tigerstedt de dömda tukthusfångarnas alldeles för små logement som lägrets värsta problem. Dessutom hölls fångarna dygnet runt i veckotal instängda utan att de fick komma ut och röra på sig i frisk luft. "Den långvariga instängningen av fångarna är snart sagt livsfarlig för dem.” Den sannolika orsaken till fångarnas bokstavliga husarrest i augustihettan var att lägret ännu inte hunnit avskilja något separat område utomhus för de dömda fångarna. Den långa kasernens nedre våning var upptagen av

55. Brev till VATO, nr IO2/I9I8, Ea I, Krigsfångeväsendets arkiv, Riksarkivet, Helsingfors.

56. Halvveckorapporter, Ec 4, Krigsfångeväsendets arkiv, Riksarkivet, Helsingfors.

57. Brev till överläkaren, nr 2II, anlänt 7/8 I9I8, Ee I, Krigsfångeväsendets arkiv, Riksarkivet, Helsingfors. 
rannsakningsfångar, som ännu inte fătt sin dom. Tigerstedt noterade också att fångarna fortfarande den 25 augusti, efter två-tre månader $\mathrm{i}$ lägret, led brist på kläder, sängar och sängkläder. De hade ingenting att dra på sig mot kölden om natten, och de gick fortfarande i sina egna, vanligen usla kläder. ${ }^{58}$ Detta trots att krigsminister Thesleff i interpellationsdebatten sju veckor tidigare gett sken av att bristen på linne- och sängkläder i lägren var åtgärdad:"I början hände det i några fängelser att fångarna inte på flera veckor kunde få rena linnekläder och var tvungna att ligga på golvet i sina kläder." ${ }^{59}$

\section{"NÅGON VERKLIG SJUKVÅRD EXISTERAR EJ"}

Det yttersta ansvaret för fångarnas hälso- och sjukvård i lägren bar SVL:s överläkare Max Björkstén. Det visade sig från början svårt att locka läkare till lägren, eftersom lönerna inte var attraktiva och förhållandena i lägren allt annat än lockande. ${ }^{60}$ Eftersom många fångar var både utmärglade och sjuka redan vid ankomsten, var det av största vikt att omedelbart få sjukvården i fånglägret organiserad.

Ekenäslägrets första läkare, den 23-årige kandidaten Arno Saxén, utnämndes redan i slutet av maj. Som chefsläkare tillträdde den 13 juni den 27-årige medicine kandidaten Toivo Ellilä. Den I4 juni hade lägret anställt åtta läkare och lika många sjuksköterskor, ${ }^{61}$ som stod inför en hopplös uppgift. Redan den 20 juni skrev Ellilä:

Sjukdomsfallen bara ökar fortfarande. Och vad tjänar det till med någon sjukvård och läkarverksamhet här, när det inte finns mat - för att inte tala om sjukhusmat, någon plats att placera patienterna, för att inte tala om sängkläder och dylikt. Flera fångar ber att de ska skjutas hellre än att de ska svältas till döds här. ${ }^{62}$

58. Brev till överläkaren, nr 272, anlänt 27/8 I9I8, Ee I, Krigsfångeväsendets arkiv, Riksarkivet, Helsingfors.

59. Återgivet i Paavolainen, Vankileirit Suomessa, s. 302-303.

6o. Paavolainen, Vankileirit Suomessa, s. 249-251.

61. Lönelistor, Gc 9, Krigsfångeväsendets arkiv, Riksarkivet, Helsingfors.

62. Ellilä till överläkaren 20/6 I9I8, nr 77, Ee I, Krigsfångeväsendets arkiv, Riksarkivet, Helsingfors. 
Läkarna lät inrätta en liten poliklinik med några rum i en byggnad och tog fångar till hjälp för att organisera sjukvården. I den kombinerade ryska kyrkan och matsalen upprättade några fångar från Gamlakarleby en liten mottagning och ett apotek i sakristian. En av dessa "förtroendefångar" var den tidigare nämnda Pekka Railo, som av läkarna fick vidsträckta befogenheter att röra sig i lägret. ${ }^{63}$

I kasernerna upprättades ett system med fångar som sanitärer. Hur det fungerade framgår ur "chefssanitären" Nordlunds rapporter. I "Åbo-avdelningen", två stall och ett lider med sammanlagt ett drygt tusental fångar, bestod sanitäravdelningen av sex man, vilka dejourerade så att det $\mathrm{i}$ varje kasern alltid fanns en som kunde dela ut vatten åt de sjuka eller eventuell medicin mot magåkommor. Enligt föreskrifterna skulle sjuka fångar erhålla lite mera mat än de övriga. Ingen av Åbofångarna hade den 26 juni sett till någon läkare, så sanitärernas omdöme avgjorde vem som var i behov av sjukhusmat. Sådan erhöll då 50 fångar $\mathrm{i}$ ”Åbo-avdelningen". ${ }^{64}$

När SVL-överläkaren Björkstén den 9 juli inspekterade Dragsvik, kunde han rapportera att en stor kasern höll på att inredas till ett sjukhus med plats för 700 patienter. Men i övrigt var sjukvårdens läge tröstlöst. I lägret fanns bara 75 filtar och inga lakan.

Sommardiarréerna äro i starkt tilltagande, och dödsfallens antal uppgår per dag till ungefär $\mathrm{I}_{5}-20$, de flesta åtminstone närmast förorsakade av tarmsjukdomar. Totala antalet dödsfall ända till och med den 6 juli är 560. Läkarnas antal är 8 och sköterskor finnas till ett antal av blott 9. Medikamenter stå knappast att få på apoteket i Ekenäs och av den från arméns huvud-depot i Tammerfors gjorda beställningen har intet kunnat erhållas. Förhållandena på sjukvårdens område te sig därför fullkomligt tröstlösa. Någon verklig sjukvård existerar ej. ${ }^{65}$

I juli inrättades ett sjukhus i den II2 meter långa västra kasernen, varifrån vaktsoldaterna från Björneborgs regemente flyttat ut. När

63. Railo, Valkoisten vankina, s. 23I-238, 256-259.

64. Nordlunds rapporter till överläkaren Ellilä, Ba I4, Ekenäs krigsfångeläger-tvångsarbetsinrättnings arkiv, Riksarkivet, Helsingfors.

65. Max Björksténs rapport till överste Wärnhjelm Io/7 I918, dokument anlända till VATO, Ea 4, Krigsfångeväsendets arkiv, Riksarkivet, Helsingfors. 
det togs i bruk, runt den 20 juli, stod nio läkarkandidater till lägrets förfogande. Två av dem hade inte tidigare tjänstgjort en enda dag på en poliklinik. ”Åt dem kan ingen självständig verksamhet överlåtas”, rapporterade läkaren Ellilä.

Den 25 juli var sjuksköterskorna nitton till antalet, men i september fanns redan ett fyrtiotal namn på lönelistan. Också fångsanitärerna blev flera, men användningen av fångar inom sjukvården var inte oproblematisk, anmärkte Ellilä:

Då erfarenheten visat att dessa i många, kanske flertalet, fall icke äro tillförlitliga, utan tillåta sig allehanda friheter och stundom svåra afvikelser från gifna föreskrifter, går det inte att på det sättet fylla bristen på sköterskor. ${ }^{66}$

Den nyutnämnde överläkaren Robert Tigerstedt ansåg vid sin inspektion i slutet av juli att sjukhuset var"i ett i allo tilltalande skick", men alltför litet för behovet. Ytterligare 200 eller 300 sjuksängar skulle ha behövts. Tigerstedt avrundade:

Behövligheten av att sjukhuset utvidgas framgår måhända allra tydligast av det sorgligaste draget i den bedrövliga bild, jag har varit nödsakad att teckna: av de $\mathrm{I} 347$ fångar, som avlidit under tiden mellan 6 juni och 3r juli, hava endast 337, d.ä. 25 procent, dött å sjukhuset, medan icke färre än I oIo avsomnat på sina träbritsar i logementen. ${ }^{67}$

Det finns många vittnesbörd om att den lokala ledningen och personalen gjorde sitt bästa under de svåra omständigheterna. Men situationen var hopplös, vilket också SVL-överläkaren Björksténs upprepade försök att under sommaren säga upp sig från sitt uppdrag vittnar om. I sin - resultatlösa - avskedsansökan till krigsminister Thesleff den 6 augusti lyfte han också fram den bristande organisationen som en orsak till lägerkatastrofen:

66. Brev till överläkaren, nr I74, Ee I, Krigsfångeväsendets arkiv, Riksarkivet, Helsingfors.

67. Brev till överläkaren, nr 2II, Ee I, Krigsfångeväsendets arkiv, Riksarkivet, Helsingfors. 
Att ordna förhållandena vid dessa läger tyckes mig nämligen omöjligt. Fångarna erhålla för litet, för enformig och möjligen även illa tillredd föda, varav följden är att de svälta och skralna av så att de lätt duka under för en tillstötande sjukdom. [...] Sammanförandet av ett för stort antal fångar till en del fångläger har gjort de hygieniska förhållandena synnerligen dåliga och för de sjuka har trots allt som gjorts en verklig sjukvård vid en del fångläger ej kunnat anordnas. Detta beror enligt min åsikt ej ensamt därpå att anskaffandet såväl av föda som en massa andra särskilt för sjukvården nödvändiga artiklar ej lyckats utan även på den omständigheten att en bestämd ordning vid fånglägren ej fåtts till stånd. ${ }^{68}$

\section{SJUKDOMARNA I EKENÄS}

Att på basis av de officiella siffrorna från lägret dra några som helst slutsatser av sjukdomsläget är vanskligt, även om exempelvis halvveckorapporterna nog uppger antalet sjukdomsfall. Till exempel den 20 juni uppgavs 543 av de 8340 fångarna ha varit sjuka. Bland dem fanns 29I fall av recurrensfeber, 69 fall av dysenteri och II2 fall av "andra sjukdomar". ${ }^{69}$ I själva verket fanns det ingen i Dragsvik som var kapabel att på ett tillförlitligt sätt diagnostisera vare sig sjukdomar eller dödsorsaker. Läkaren Ellilä medgav själv i ett brev till överläkaren att han inte säkert kunnat diagnostisera till exempel recurrensfebern, utan antog att det rörde sig om den sjukdomen utifrån rapporter från Gamlakarleby. Officiell statistik och verklighet var två separata saker i Dragsvik. Enligt halvveckorapporten den I juli var sjukdomsfallen i lägret 67I, men enligt sanitären Nordlunds rapport låg I 44I fångar samma dag sjuka i kasernerna. ${ }^{70}$

Sjukdomarna anlände till Dragsvik med de första fångtransporterna. Närpesfångarna var drabbade av rödsot, eller dysenteri, en akut tarminflammation förorsakad av bakterier, som smittade genom orent vatten och förskämd mat, och gav upphov till försvagat allmäntillstånd,

68. Brevkoncept I9I8, Da I, Ekenäs krigsfångeläger-tvångsarbetsinrättnings arkiv, Riksarkivet, Helsingfors.

69. Halvveckorapporter, Ec 4, Krigsfångeväsendets arkiv, Riksarkivet, Helsingfors.

70. Nordlunds rapport, $\mathrm{Ba}$ I4, Ekenäs krigsfångeläger-tvångsarbetsinrättnings arkiv, Riksarkivet, Helsingfors; Brev till överläkaren, nr 70, Ee I, Krigsfångeväsendets arkiv, Riksarkivet, Helsingfors. 
intensiv diarré och blod i avföringen. Enligt Pekka Railo avled 88 av de 344 Närpesfångarna under de första tio veckorna i Dragsvik. Att inte flera av dem dog berodde uppenbarligen på att de från början isolerades i en egen kasern och fick bättre mat än de andra fångarna. ${ }^{71}$ Dysenterin kunde begränsas till Närpeskasernen, som också fick ett eget kök för mathanteringen.

Fångarna från Brahestad led bokstavligen alla av marasmus, det vill säga allvarlig undernäring. ”Av dem dör flera dagligen trots all vård och försök att mata dem”, skrev Ellilä. ${ }^{72}$ I Brahestad hade roo fångar bedömts vara för svaga för att kunna sändas till Ekenäs. Av dem som bedömdes vara friska nog att sändas iväg avled en under natten före avfärden, sexton kroknade på vägen till stationen och fyra omkom under resan till Ekenäs. Inom tio veckor, hävdar Railo, avled I69 av de 478 fångar som anlände från Brahestad till Dragsvik. Lägret i Brahestad hade under våren haft åtminstone 3I smittkoppspatienter, varav fem avlidit. Risken för att den fruktade sjukdomen skulle spridas också till Ekenäs föreföll överhängande. Enligt Railo identifierades tre smittkoppspatienter genast vid ankomsten, isolerades och fördes direkt till epidemisjukhuset. Därefter undgick Dragsvik tydligen nya fall av smittkoppor, trots att sjukdomen ofta var besvärlig i andra läger. ${ }^{73}$

De redan tidigare nämnda fångarna från Gamlakarleby var, som konstaterats, drabbade av recurrensfeber redan innan de sändes till Dragsvik. I Ekenäs klagade provinsialläkaren Reinhold Fabritius till Medicinalstyrelsen över att han först i efterskott fått besked om tågets ankomst, och förundrade sig över hur sjuka fångar transporterades runt i landet. Järnvägsförvaltningen hade inte heller vidtagit några som helst försiktighetsåtgärder, och de sannolikt smittbärande järnvägsvagnarna sändes direkt vidare till andra orter. ${ }^{74}$

7I. Railo, Valkoisten vankina, s. 239 f. Railo sade sig ha fört bok över dödsfallen i lägret. Hans anteckningar beslagtogs vid hans frigivning på hösten, men han hade skrivit av dem och smugglade ut avskriften ur lägret.

72. Brev till överläkaren, nr 70, I9/6 I9ı8, Ee I, Krigsfångeväsendets arkiv, Riksarkivet, Helsingfors.

73. Paavolainen, Vankileirit Suomessa, s. 265; Mäkelä, Vuosien I9I7-I9I9 kulkutaudit, s. 215 ff; Railo, Valkoisten vankina, s. 262, 288; Brev till VATO, Ea I, Krigsfångeväsendets arkiv, Riksarkivet, Helsingfors.

74. Provinsialläkare Fabritius brev till Medicinalstyrelsen 3/6 I9I8, Brev till överläkaren, $\mathrm{nr}$ 65, Ee I, Krigsfångeväsendets arkiv, Riksarkivet, Helsingfors. 
Recurrensfeber, eller skyttegravsfeber (febris recurrens), förorsakas av en med borrelia besläktad spiroket som kommer in i blodomloppet och sprids genom lössbett. Sjukdomen kan drabba olika inre organ, leda till hjärtmuskel- eller lunginflammation, tarminflammation, mjältbrand och dylikt. Innan moderna mediciner togs i bruk uppskattades dödligheten till $20-40$ procent. ${ }^{75}$ Recurrensfebern hade spridit sig bland befästningsarbetare i Helsingfors redan våren I9I7. Våren 1918 bröt en epidemi ut i Tammerfors, och i maj drabbades också Gamlakarleby. Därvarande distriktsläkarens order om karantän för sjuka fångar ignorerades, liksom uppmaningarna att bekämpa lössen och förbättra hygienen. När kommendanten i början av juni sände de 800 fångarna till Ekenäs, var runt 500 av dem drabbade av sjukdomen. Två veckor senare diagnostiserades 375 fall av recurrensfeber i Ekenäs. ${ }^{76}$ I Dragsvik, där det myllrade av löss, spred sig sjukdomen okontrollerat i de trångbodda och ohygieniska förhållandena. Pentti Mäkelä konstaterar att snart sagt alla fångar i Dragsvik i något skede infekterades av sjukdomen, som också spreds till lägerpersonalen och befolkningen utanför lägret.

Sommaren I9I8 tillbakavisade dock professor Tigerstedt påståendet att recurrensfebern skulle ha varit orsaken till den höga dödligheten och hävdade att epidemin till största delen var över redan i mitten av juli. I ljuset av senare uppgifter misstog sig Tigerstedt. Samtidigt är det uppenbart att också andra febersjukdomar grasserade i Ekenäs under sommaren. På nationell nivå var A-influensaepidemin,"spanska sjukan", den främsta dödsorsaken under sommaren I9I8 och antas ha dödat 4 000-5 000 fångar. Den nådde sin kulmen i juli. ${ }^{77}$ Dragsvik tycks ändå ha förskonats från den; enligt lokaltidningen Vestra Nyland hade i juli ännu inga allvarligare influensafall noterats i Ekenäs. På hösten blev läget värre, och i november tycks epidemin ha drabbat stadens skolor. ${ }^{78}$ Men någon starkt bidragande orsak till massdöden i Dragsvik sommaren I9I8 var spanska sjukan uppenbarligen inte.

75. Mäkelä, "Tammisaaren täihelvetti", s. $352 \mathrm{f}$.

76. Ibid., s. 353; Mäkelä, "Epidemisiin sairauksiin menehtyneet", s. I39-I44.

77. Ibid., s. I44-I50; Eija Linnanmäki,"Spanska sjukan i Finland", Finska läkaresällskapets handlingar, årgång 166, nr I/2006, s. 76-85; Sami Suodenjoki, "Vankileirit", Pertti Haapala \& Tuomas Hoppu (toim.), Sisällissodan pikkujättiläinen, s. 350.

78. Vestra Nyland 27/7 I918, 2/II I9I8. 
Hur osäkra sjukdomsdiagnoserna I9ı8 kunde vara framgår av de brev som lägerläkaren Richard Sievers på Sveaborg sände till SVLchefen Feodor Roos rörande de 700 Dragsvikfångar som den I 7 augusti anlände till Sveaborg. Där måste I7o av dem genast inta sängläge, och omkring too hade hög feber."Det låg så att säga ett annat sjukdomsdrag över denna Ekenäs-grupp än över de fångar jag tidigare mottagit från andra orter. De voro trötta, matta, hade en svartgul ansiktsfärg, flere sågo bleka, solbrända ut", skrev Sievers, som i början av september upptäckte Spirockete Obermeieri hos fångarna och därmed kunde säkerställa sjukdomsdiagnosen.

Det är därför tämmeligen säkert att de talrika fall av höga temperaturstegringar med hastigt fallande feber som vi iakttagit hos en stor mängd bland de från Ekenäs anlända făngarna bero på förhandenvaro av typhus recurrens bland dem, och icke på influenza, som man de första dagarna ville hoppas vara fallet.

Detta var de första fallen av sjukdomen på Sveaborg. Man kan notera att Sievers hade hoppats på att sjukdomsfallen skulle ha varit influensa, det vill säga spanska sjukan. Av de 700 Dragsvikfångarna avled femton under den första veckan på Sveaborg. Av lägrets övriga 4600 fångar dog under samma tid 30 . Följande vecka avled 29 av Dragsvikfångarna, exakt lika många som av Sveaborgs övriga fångar. ${ }^{79}$ Den extra katastrofala sjukdomssituationen i Ekenäslägret framgår av att Medicinalstyrelsen den 6 september beordrade att fångar från Ekenäs inte skulle få släppas på fri fot eller förflyttas, om man inte var helt säker på att de inte spred några smittsamma sjukdomar. Detta föranleddes av rapporter om att fyra Dragsvikfångar efter frigivningen insjuknat i recurrensfeber i Fredrikshamn, liksom en flicka i Vederlax som vistats i samma hus som en frigiven och strax därpå avliden fånge. ${ }^{80}$

79. Överläkarens brevkoncept 4/9 I9I8, Dc I, Krigsfångeväsendets arkiv, Riksarkivet, Helsingfors.

8o. Medicinalstyrelsens brev till överläkaren 6/9 I9I8, nr 275, Ee I, Krigsfångeväsendets arkiv, Riksarkivet, Helsingfors. 
Hur dödligheten i Dragsvik steg i augusti framgår av Robert Tigerstedts andra rapport den 25 augusti. På 25 dagar hade 726 fångar avlidit, i medeltal 29 fångar per dag, samtidigt som fångarnas antal minskat. ${ }^{81}$ Vid det laget var det bara i Dragsvik som dödligheten fortfarande steg. Lägret stod för 55 procent av alla registrerade dödsfall bland röda fångar i augusti i9ı8. Enligt rapporterna avled där i augusti drygt 800 fångar, medan till exempel Tavastehuslägret noterade drygt 200 döda, och Lahtis, där det fanns flera fångar än i Ekenäs, drygt I50. ${ }^{82}$

Den 15 september överfördes de finländska fånglägren från arméns till den civila fångvårdsstyrelsens kontroll. Fånglägret i Ekenäs blev nu officiellt Ekenäs tvångsarbetsinrättning, och mer ordnade förhållanden inträdde samtidigt som dödligheten snabbt sjönk. I oktober avled 8I fångar, i november I6 och i december I3. Samtidigt släpptes redan dömda fångar fria i och med höstens amnestier. Vid årsskiftet I9I9 fanns I 042 fångar kvar i lägret. ${ }^{83}$

En allmänt spridd samtida uppfattning var att lägerfångarna avled på grund av de sjukdomar de smittats av under kriget. Krigsminister Thesleff skyllde i juli dödligheten på "att de upproriska varit i nära beröring med trupperna från öster och därigenom smittats av de epidemier som härjar i Ryssland". ${ }^{84}$ Detta tillbakavisades av professor Tigerstedt, som påpekade att några större epidemier av smittsamma sjukdomar inte rasat i lägret. I stället menade han att den främsta orsaken till det stora antalet döda låg i kombinationen mellan dåliga hygieniska förhållandena i lägret och den knappa tillförseln av näring. I ljuset av den senaste forskningen förefaller Tigerstedt inte helt ha insett recurrensfeberns stora roll i dödligheten, men samtidigt hade ju den sjukdomen och de usla hygieniska förhållandena ett nära samband.

8I. Robert Tigerstedts rapport till överläkaren, nr 273, Ee I, Krigsfångeväsendets arkiv, Riksarkivet, Helsingfors.

82. Paavolainen, Punavankileirit Suomessa, s. 244.

83. Eerola, Ekenäs I9I8, s. I9, 35 .

84. Paavolainen, Punavankileirit Suomessa, s. 303. 
Det är uppenbart att den höga dödligheten i Dragsvik förorsakades av många samverkande faktorer. Lägrets svaga organisation, liksom ledningens - både den lokala i Ekenäs och den centrala i Helsingfors - oförmåga att åstadkomma ordnade sanitära förhållanden spelar en viktig roll i sammanhanget. Den svaga allmänkonditionen särskilt bland de österbottniska fångarna som sändes till Dragsvik var en avgörande orsak till att dödligheten exploderade just i det lägret. De utmärglade fångarnas motståndskraft mot sjukdomar var nedbruten, och i de trånga, ohygieniska förhållandena i kasernerna spreds farsoter som en löpeld. Därtill spelade säkerligen också psykiska faktorer en betydelsefull roll för dödligheten. Marko Tikka har noterat hur fångarnas mentala sammanbrott $i$ samband med tillfångatagandet och lägervistelsen ofta följdes av ett rent fysiskt sammanbrott. ${ }^{85}$

De fångar som fătt sig tilldelad någon arbetsuppgift tycks ha haft större chanser att klara sig med livet i behåll. Dels kunde det bero på att de erhöll större matportioner, dels på att de i sin position kunde smyga åt sig extra ransoner. Men också professor Tigerstedt ansåg att sysslolösheten, som den stora majoriteten av fảngarna tvingades leva i, var fördärvlig och betraktade den som en direkt orsak till den höga dödligheten. I Dragsvik var i mitten av juli bara runt 550 fångar, mindre än to procent, sysselsatta med någon arbetsuppgift, vilket var betydligt mindre än i de flesta andra läger. ${ }^{86}$

Fånglägret i Dragsvik sommaren I9I8 framstår som den sannolikt största humanitära katastrofen i det moderna Finlands historia. Någon medveten strävan att beröva fångarna livet kan ändå inte skönjas, även om man förstås kan diskutera i vilken mån myndigheternas

85. Marko Tikka, Terrorin aika. Suomen levottomat vuodet I9I7-I92I, Helsinki: Ajatus kirjat 2006, s. I69.

86. Paavolainen, Vankileirit Suomessa, s. 282-288. Frågan om fångarnas inre hierarki, vem som sysselsattes hur och var, och kampen om tillvaron i fånglägren är tämligen outredd och förtjänar en separat undersökning. I denna artikel finns inte plats för en fördjupning i dessa aspekter av lägret i Dragsvik. 


\section{och lägerledningens visade nonchalans och underlåtenhet att rätta till olägenheter bidrog till förlusterna av människoliv. ${ }^{87}$}

87. Drygt två decennier senare stod Finland inför en liknande situation med fångar. Av de omkring 67000 sovjetiska soldater som togs till fånga vid fortsättningskrigets början dog minst I9 000 men sannolikt mer än 22000 i finländsk krigsfångenskap, de flesta redan vintern I94I-I942. Enligt Mirkka Danielsbacka hade dödligheten samma orsaker som I9I8. Den viktigaste dödsorsaken var utmärgling på grund av undernäring, eftersom fångarna erhöll för lite näring i förhållande till det arbete de utförde. Den dåliga hygienen i fånglägren och de trånga boendeförhållandena underlättade spridningen av infektioner, vilket blev ödesdigert för de undernärda och dåligt utrustade krigsfångarna under den kalla vintern I94I-I942. Danielsbacka anser dock inte att den höga dödligheten skulle ha varit resultatet av någon medveten strävan att ta livet av fångarna. Mirkka Danielsbacka, Sotavankikohtalot. Neuvostovangit Suomessa I94I-I944, Helsinki: Tammi 2016, s. 287. Boken baserar sig på Danielsbackas doktorsavhandling Vankien vartijat: Ihmislajin psykologia, neuvostosotavangit ja Suomi 194I-1944, Historiallisia tutkimuksia Helsingin yliopistosta 32, Helsinki: Helsingin yliopisto 2013 